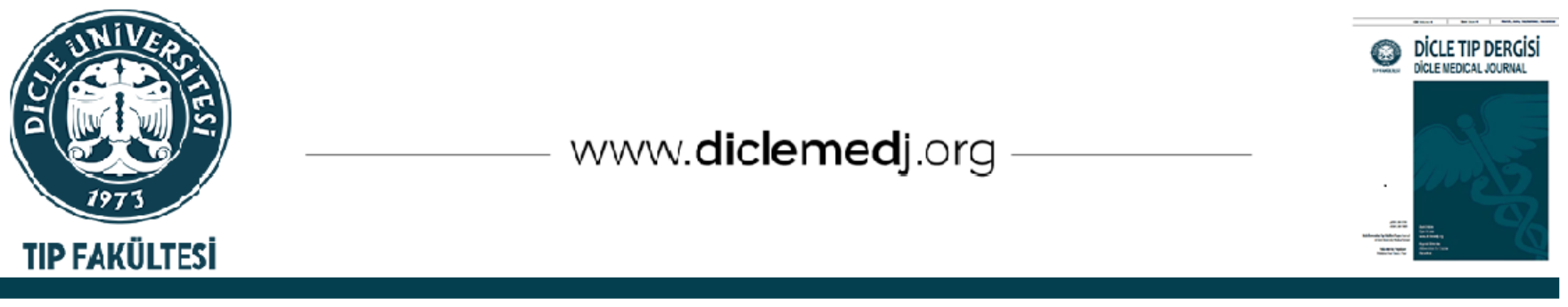

\title{
Tilt Table Tedavisi Uygulanan Nörolojik Rehabilitasyon Hastalarında Ortostatik Hipotansiyon Gelişimi ile Anksiyetenin İlişkisi
}

\author{
Selma Eroğlu ${ }^{1}{ }_{1}$ \\ 1 Afyonkarahisar Sağlık Bilimleri Üniversitesi Tıp Fakültesi, Fiziksel Tıp ve Rehabilitasyon Anabilim Dalı, Afyonkarahisar, \\ Türkiye
}

Geliș: 02.04.2021; Revizyon: 08.08.2021; Kabul Tarihi: 09.08.2021

Öz

Amaç: Nörolojik rehabilitasyon uygulanan hastalarda sıklıkla görülen ortostatik hipotansiyon $(\mathrm{OH})$, yaşam kalitesini ve bağımsızlığı azaltmakta, hastanede yatış süresini artırmaktadır. Tilt table'da vasovagal senkop gelişen hastalarda anksiyetenin semptomları tetiklediği bildirilmiştir. Nörolojik rehabilitasyon hastalarında anksiyete sıklıkla görülür. Ancak, nörojenik $\mathrm{OH}$ ile anksiyete arasındaki ilişki incelenmemiştir. Bu çalışmada tilt table tedavisi (TTT) uygulanan nörolojik rehabilitasyon hastalarında $\mathrm{OH}$ gelişimiyle anksiyete arasındaki ilişkinin incelenmesi amaçlandı.

Yöntemler: Nörolojik rehabilitasyon ve TTT uygulanan hastaların yaşı, cinsiyeti, tanısı ve hastalık süresi kaydedildi. Hastalar Fonksiyonel Bağımsızlık Ölçeği (FBÖ) ve Beck Anksiyete Ölçeği (BAÖ) ile değerlendirildi. TTT sırasında nörojenik $\mathrm{OH}$ gelişip gelişmediği ve gelişme süresi (dakika) kaydedildi.

Bulgular: Çalışmaya alınan 39 hastanın (12 kadın) yaş ortalaması 43ะ17,7 yıldı. Hastalardan 22'sinde OH gelişti. Hastalar $\mathrm{OH}(+)$ ve $\mathrm{OH}(-)$ şeklinde gruplandığında yaş, cinsiyet, hastalık süresi ve FBÖ skorları benzerdi (tümü için p>0.05), BAÖ skorları arasında da anlamlı fark izlenmedi ( $\mathrm{p}=0.580)$. OH (+) hastalar anksiyete düzeylerine göre (minimal, hafif, orta, yüksek) gruplandırıldı ve gruplar arasında $\mathrm{OH}$ gelişim süresi açısından fark gözlenmedi $(\mathrm{p}=0.424)$. $\mathrm{OH}$ gelişim süresiyle anksiyete, yaş, hastalık süresi ve FBÖ arasında ilişki izlenmedi. Cinsiyet açısından incelendiğinde, OH (+) kadınlarda anksiyete skoru erkeklere kıyasla daha yüksekken $(\mathrm{p}=0.048), \mathrm{OH}(-)$ grupta cinsiyet açısından anksiyete skoru benzerdi $(\mathrm{p}=0.111)$.

Sonuç: Nörolojik rehabilitasyon uygulanan hastalardan TTT alanlarda nörojenik $\mathrm{OH}$ gelişimi ile anksiyete arasında ilişki gösterilemedi. $\mathrm{OH}(+)$ kadın hastaların anksiyete skorları erkek hastalara oranla daha yüksek bulundu. Nörojenik OH'lu kadın hastalarda yüksek anksiyetenin klinik öneminin ve hasta özelliklerine göre yaklaşım sonuçlarının belirlenmesi açısından daha kapsamlı çalışmalara ihtiyaç vardır.

Anahtar kelimeler: Nörolojik rehabilitasyon; ortostatik hipotansiyon; tilt table tedavisi; anksiyete

DOI: $10.5798 /$ dicletip.988073

Correspondence / Yazıșma Adresi: Selma Eroğlu, Afyonkarahisar Sağlık Bilimleri Üniversitesi Hastanesi, Fiziksel Tıp ve Rehabilitasyon Anabilim Dalı, Zafer Sağlık Külliyesi Dörtyol Mah. 2078 Sokak, No: 3, A Blok, PK: 03030, Afyonkarahisar, Türkiye e-mail: seroglu79@gmail.com 


\title{
The Association of Anxiety with the Emergence of Orthostatic Hypotension in Patients Undergoing Tilt Table Therapy Throughout Neurologic Rehabilitation
}

\begin{abstract}
Objective: Orthostatic hypotension $(\mathrm{OH})$, which is frequent in patients undergoing neurological rehabilitation, decreases the quality of life and independence and increases hospital-stay. Anxiety triggers symptoms of vasovagal syncope in patients on tilt table. Anxiety is frequent in patients undergoing neurological rehabilitation. However, the association between neurogenic $\mathrm{OH}$ and anxiety is unclear. This study aimed to investigate the relationship between the emergence of $\mathrm{OH}$ and anxiety in patients undergoing tilt table therapy (TTT) throughout neurological rehabilitation.
\end{abstract}

Methods: The age, gender, diagnosis and disease duration of the patients on TTT were recorded. They were evaluated using the Functional Independence Measurement (FIM) and the Beck Anxiety Inventory (BAI). Emergence of neurogenic $\mathrm{OH}$ (if present) and time to emergence (minutes) were recorded.

Results: The mean age of 39 patients ( 12 female) was $43 \pm 17,7$ years. $0 H$ emerged in 22 patients. When the patients were grouped as $\mathrm{OH}(+)$ and $\mathrm{OH}(-)$, demographic characteristics and FIM scores were similar ( $\mathrm{p}>0.05$ for all), BAI scores were also similar $(\mathrm{p}=0.580)$. When $\mathrm{OH}(+)$ patients were grouped regarding anxiety levels (minimal, mild, moderate, high), duration to $\mathrm{OH}$ were similar between the groups $(\mathrm{p}=0.424)$. There was no relationship between the duration to $\mathrm{OH}$ and anxiety, age, disease duration and FIM. Regarding gender, the anxiety score was higher in $\mathrm{OH}(+)$ women than in $\mathrm{OH}(+)$ men $(\mathrm{p}=0.048)$, while the anxiety score within the $\mathrm{OH}(-)$ group was similar $(\mathrm{p}=0.111)$

Conclusion: There was no relationship between the emergence of neurogenic $\mathrm{OH}$ and anxiety in patients undergoing TTT throughout neurological rehabilitation. Anxiety scores of $\mathrm{OH}(+)$ females were higher than $\mathrm{OH}(+)$ males. Comprehensive studies are needed to determine the clinical significance of high anxiety in neurogenic $\mathrm{OH}(+)$ females and the results of the approach according to patient characteristics.

Keyword: Neurologic rehabilitation; orthostatic hypotension; tilt table therapy; anxiety.

\section{GíRiş}

Nörolojik rehabilitasyon uygulanan hastalarda görülen ortostatik hipotansiyon $(\mathrm{OH})$, var olan duyusal ve motor bozukluklara ek olarak yașam kalitesini ve günlük yaşam aktivitelerindeki bağımsızlığı azaltmakta ve düşme riskini artırmaktadır ${ }^{1-3}$. Ayrıca, bu durum nörolojik rehabilitasyon uygulanan hastalarda hastanede kalış süresini uzatmaktadır ${ }^{2,4}$. Tilt table uygulaması, nörojenik $\mathrm{OH}$ tanısında ve nörolojik rehabilitasyonun bir parçası olarak tedavisinde kullanılmaktadır. $\mathrm{OH}$, supin pozisyonundan dik durma pozisyonuna geçildiğinde veya tilt table ile $60^{\circ}$ kaldırıldığında 3 dakika içinde, semptomlardan bağımsız olarak, sistolik kan basıncında en az 20 $\mathrm{mmHg}$, diyastolik kan basincinda ise en az 10 mmHg düşme olması şeklinde tanımlanmaktadır ${ }^{1,3}$. Nörojenik $\mathrm{OH}^{\prime}$ da baș dönmesi, kulak çınlaması, bulantı, yorgunluk hissi, kognitif bozukluk, baș ve boyun ağrısı, çarpıntı, bilinç bulanıklığı, senkop ve düşme görülebilir1-3. Nörojenik $\mathrm{OH}$ prevalansı hastalıklar arasında değişmekle birlikte sık görülen ve rehabilitasyon sürecini olumsuz etkileyen bir tablodur. Altmışbeş yaş üzerindeki bireylerin \%30'unda, yatarak tedavi gören hastaların \%70'inde, Parkinson hastalarının \%30'unda, multi sistem atrofisi bulunan hastaların \%80'inde ve spinal kord yaralanması (SKY) bulunan hastaların 1/3'ünde görülmektedir ${ }^{1,5}$. Bu durum otonomik postural cevapların yetersizliğine bağlıdır ${ }^{1,6}$, multifaktöriyel bir mekanizma ile ortaya çıkmaktadır ve ilaçlar, hipovolemi, kardiyovasküler hastalıklar nedeniyle semptomlarda artış görülebilmektedir ${ }^{7,8}$.

Nörolojik rehabilitasyon uygulanan hastalarda OH serebral kan akımında azalma ve buna bağlı olarak kognitif fonksiyon bozukluğu, motivasyon düşüklügü, dikkat eksikliği hiperaktivite bozukluğu ve demans ile 
ilișkilidir'9. SKY'li hastalarda nörojenik $\mathrm{OH}$ hastanın tedaviye katılımını kısıtlar, vertikalizasyon ve tekerlekli sandalye kullanımını azaltır ${ }^{2,4,10}$. Katkıda bulunan birçok biyolojik ve olası psikolojik faktörler nedeniyle nörojenik $\mathrm{OH}^{\prime} u$ doğru bir şekilde ele almak ve tedavi etmek zor olabilir. $\mathrm{Bu}$ nedenle bu hastalarda $\mathrm{OH}$ ve ilişkili faktörlerin daha iyi anlaşılması etkili tedavilerin geliştirilmesine ve tabloyu kötüleştiren faktörlerin elimine edilmesine imkan sağlayabilir.

Tilt table'da vasovagal senkop gelişen hastalarda yapılan çalışmalarda anksiyete yaygın olarak görülmüştür. $\mathrm{Bu}$ hastalarda anksiyetenin, senkobun tetikleyicisi mi yoksa senkoba sekonder $\mathrm{mi}$ ortaya çıktığı net olmamakla birlikte semptomları kötüleștirici etkisi olduğu bildirilmiştir ${ }^{11,12}$. Benzer șekilde SKY'nda otonom sinir sistemi tutulumuyla ilişkili tablolardan birisi olan otonomik disrefleksi konusunda yapılan çalışmalarda emosyonel faktörlerin, özellikle anksiyetenin, otonomik disrefleksiyi tetiklediği bilinmektedir ${ }^{13}$. Psikolojik faktörlerin vazovagal senkop gelişiminde rolü olduğu düşünüldüğünde, nörojenik $\mathrm{OH}$ gelişiminde de böyle bir etki bulunması durumu akla gelmektedir. Ancak, bildiğimiz kadarıla, literatürde nörojenik $\mathrm{OH}$ gelişiminde ve/veya semptomların kötüleşmesinde psikolojik faktörlerin etkisi şu ana kadar tam olarak açıklanmamıştır.

\section{Bu çalışmanın hipotezleri şu şekildeydi;}

1) Anksiyetesi yüksek olan hastalarda nörojenik $\mathrm{OH}$ daha sık ortaya çıkar.

2) Nörojenik $\mathrm{OH}$ gelişen hastalarda anksiyete düzeyi yükseldikçe $\mathrm{OH}$ gelişim süresi kısalır.

3) Nörojenik $\mathrm{OH}$ gelişen hastalarda anksiyete, yaş ve hastalık süresi arttıkça ve fonksiyonel durum kötüleştikçe $\mathrm{OH}$ gelişim süresi kısalır.

$\mathrm{Bu}$ amaçla bu çalışmada, literatürde ilk kez, tilt table tedavisi uygulanan nörolojik rehabilitasyon hastalarında $\mathrm{OH}$ gelişimi ile anksiyete arasındaki ilişki ve $\mathrm{OH}$ gelişim süresinin hastanın anksiyete düzeyinden ve hastayla ilgili yaş, cinsiyet, hastalık süresi ve fonksiyonel durum gibi parametrelerden etkilenip etkilenmediği incelendi.

\section{YÖNTEMLER}

Çalışma yerel etik kurul tarafından onaylandı (Afyonkarahisar Sağlık Bilimleri Üniversitesi Klinik Araştırmalar Etik Kurulu- 05.02.20212021/111) ve veri toplamaya başlamadan önce tüm hastalar çalışma prosedürü hakkında bilgilendirildi ve kendilerinden gönüllü olur formu alındi.

Afyonkarahisar Sağlık Bilimleri Üniversitesi Tıp Fakültesi Fiziksel Tıp ve Rehabilitasyon ünitesinde Şubat ve Mart 2021 dönemlerinde yatarak nörolojik rehabilitasyon uygulanan, hastalık süresi en az 4 hafta olan ve rehabilitasyona ek olarak tilt table tedavisi alan, 18 yaşından büyük hastalardan çalışmaya katılmayı kabul edenler başvuru sırasına göre çalışmaya dahil edildi. Kontrolsüz hipertansiyon, kardiyovasküler hastalık, psikiyatrik hastalı (anksiyete/depresyon), iletişim bozukluğu, ciddi kognitif fonksiyon bozukluğu ve (anksiyete/depresyon ile ilgili) psikiyatrik ilaç kullanım öyküsü olan hastalar ise dışlandı. Dışlama kriterlerinin varlığı, hastanın öyküsünün ve tıbbi kayıtlarının değerlendirilmesi ile tespit edildi.

Hastaların yaşı, cinsiyeti, tanısı, hastalık süresi ve eşlik eden hastalıkları kaydedildi. Değerlendirmeler nörolojik rehabilitasyonun ilk haftasinda tilt table tedavisinin hemen öncesinde yapıldı. Her hastanın yalnızca bir tilt table tedavisi değerlendirmeye alındı.

\section{Fonksiyonel Bağımsızlık Ölçeği}

Hastaların günlük yaşam aktivitelerindeki bağımsızlık düzeyleri, hekim tarafından Fonksiyonel Bağımsızlık Ölçeği (FBÖ-FIM) kullanılarak değerlendirildi. FBÖ, kişinin günlük temel fiziksel ve kognitif aktivitelerindeki 
bağımsızlık düzeyini değerlendirmek amacıyla kullanılır. Değerlendirme, motor ve kognitif FBÖ olarak iki kısımda yapılmaktadır. Motor fonksiyon değerlendirmesi kendine bakım, sfinkter kontrolü, mobilite, lökomosyon kategorilerini içerirken, kognitif fonksiyon değerlendirmesi iletişim ve sosyal algılama kategorilerini içerir. Fonksiyonel disabiliteyi belirleyen toplam 18 başlık altında, her soru 1 (tamamen yardıma ihtiyaç duyan) ile 7 (tamamen bağımsız) arasında puanlanır, 1'den 5'e kadar olan puanlar kişinin bakıcı yardımına ihtiyacl olduğunu gösterir. FBÖ'nden alınabilecek minimum skor 18 iken, maksimum skor 126'dır. Artan skorlar hastanın fonksiyonel bağımsızlık düzeyinin arttığını gösterir'14. FBÖ, rehabilitasyon hastalarında güvenilir, geçerli ve yüksek iç tutarlılık gösteren bir araçtır. Yatarak rehabilitasyon uygulanan hastalarda ve evde bakım ortamlarında fonksiyonel aktivite düzeyini ölçmek için kullanılır. Bu çalışmanın içerdiği hasta gruplarında da (spinal kord yaralanması, inme, travmatik beyin hasarı ve Parkinson Hastalığı) geçerli olduğu bildirilmiștir ${ }^{15-17}$. FBÖ'nin Türkçe geçerlik ve güvenilirliği daha önce Küçükdeveci ve ark. tarafından yapılmıştır ${ }^{18}$.

\section{Beck Anksiyete Ölçeği}

Hastaların anksiyete düzeyi, Beck Anksiyete Ölçeği (BAÖ) kullanılarak değerlendirildi. BAÖ, bireylerin yaşadığı anksiyete belirtilerinin şiddetinin belirlenmesi amacıyla kullanılır. BAÖ, uygun maliyeti, verimliliği, kolaylıkla uygulanması, yorumlanması ve tamamlanması nedeniyle birçok farklı hasta popülasyonunda anksiyete düzeyinin belirlenmesi için sıklıkla kullanılan bir araç haline gelmiştir. BAÖ, anksiyetenin şiddetini değerlendirmek için oluşturulmuş 21 başlık içeren Likert tipi bir ölçektir, hastalar öz değerlendirmeleri ile her bir başlık için 0-3 arasında puanlama yapar. Her başlık için verilen yanıtlar; hiç (0 puan), hafifancak beni çok etkilemedi (1 puan), orta düzeyde- hoş değildi ancak katlanabildim (2 puan) ve ciddi düzeyde- dayanmakta çok zorlandım (3 puan) şeklinde değişir. BAÖ'den alınabilecek skor 0-63 arasında değişir ve alınan skor ne kadar yüksekse bireyin yaşadığı anksiyetenin şiddeti o kadar yüksektir. Alınan skorlara göre anksiyete şiddeti şu şekilde değerlendirilir; 0-7: minimal düzeyde anksiyete, 8-15: hafif düzeyde anksiyete, 16-25 orta düzeyde anksiyete ve 26-63: yüksek düzeyde anksiyete ${ }^{19,20}$. BAÖ'nün Türkçe geçerlik ve güvenilirliği Ulusoy ve ark. tarafından yapılmıştır ${ }^{19}$.

\section{Tilt Table Uygulaması}

Kliniğimizdeki rehabilitasyon ünitesinde, nörolojik rehabilitasyonun bir parçası olarak tilt table tedavi protokolü şu şekilde uygulandı.

Hastaların tedavi öncesinde en az 4 saat aç olmaları önerildi ${ }^{21}$. İşlem öncesi kan basıncı ölçümleri, hastalar tilt masasına alınmadan önce $30^{\circ}$ baş yüksekliği ile hastane yatağında minimum 10 dakika dinlendikten sonra yapıldı. Hastalar daha sonra tilt masasına alınd, kemerler kullanılarak göğüs, pelvis ve diz bölgelerinden tilt masasına sabitlendi, ayak tabanından bir plaka ile desteklendi ve ilk olarak $45^{\circ}$ ye kaldırılarak 5 dakika beklendi. Üçüncü dakikadan itibaren başlanarak beşer dakika ara ile hastanın uygulamaya toleransı, çalışmayı yürüten hekim, ünitede görevli hemşire ve terapist tarafından kan basıncı ölçümü ve intolerans bulguları ile değerlendirildi. Herhangi bir eğim açısında hastada intolerans bulguları (baş dönmesi, bulantı, sersemlik hissi, bayılma, terleme, halsizlik, çarpıntı) ortaya çıkması ve/veya sistolik kan basıncinda en az $20 \mathrm{mmHg}$, diyastolik kan basıncında ise en az $10 \mathrm{mmHg}$ düşme olması durumunda uygulama sonlandırıldı, hasta yatay istirahat pozisyonuna alındı, vital bulguları değerlendirildi ve bu hastalara $\mathrm{OH}$ tanısı konuldu. Kırk beş derece elevasyonu başarılı şekilde tamamlayan hastalarda uygulama adım adım artırılarak $60^{\circ}$, 
$70^{\circ}, 80^{\circ}$ ve $90^{\circ}$ olacak şekilde devam edildi. Altmış derece üzerindeki açıları tolere edebilen hastalarda en fazla 20 dakika süreyle uygulama yapıldı, intolerans belirtileri görülürse, protokol sonlandirıld ve hasta yatay pozisyona döndürüldü22. Tedavi sırasında $\mathrm{OH}$ gelişip gelişmediği ve $\mathrm{OH}$ gelişen hastaların hangi semptomları tariflediği ve semptomların kaçıncı dakikada geliştiği hekim tarafından kaydedildi.

\section{İstatistiksel Analiz}

Post-hoc analiz için G-Power (G-Power sürüm 3.1.9.7, Almanya) programı kullanıldı. Çalışma populasyonunda $(\mathrm{OH}$ gelişen grup $(\mathrm{n}=22), \mathrm{OH}$ gelişmeyen grup (n=17)) 0.84 etki büyüklüğü ile \%5 Tip 1 hata kullanılarak yapılan analizde çalışmanın gücü $\% 80$ olarak hesaplandı.

İstatistiksel analizler SPSS versiyon 20.0 yazılımı (IBM Corp.,Armonk, NY, ABD) kullanılarak yapıldı. Elde edilen verilerin normal dağılıma uygunluğu Kolmogorov-Smirnov testi ile incelendi. Tanımlayıcı verilerden normal dağılıma uyan yaş ve FBÖ verileri ortalama \pm standart sapma şeklinde, normal dağılıma uymayan diğer tüm veriler ise median (minimum-maksimum) şeklinde verildi. Kategorik veriler hasta sayısı(n) ve yüzde(\%) olarak verildi. İki grubun ölçümsel verilerinin karşılaştırılmasında normal dağılıma uyan hasta yaşı ve FBÖ verileri Student-t testi, bu iki veri dışında normal dağılıma uymayan diğer tüm verilerde iki grubun karş̧laştırılmasında Mann-Whitney U testi kullanıld. Kategorik verilerin karşılaştırılması Ki-kare testi kullanılarak yapıldı. Numerik veriler arasındaki ilişkiyi ölçmede normal dağılım göstermeyen veriler için Spearman, normal dağılım gösteren veriler için Pearson korelasyon testleri uyguland. $\mathrm{OH}$ gelişen hastaların anksiyete düzeyleri ile $\mathrm{OH}$ gelişim süresi arasındaki ilişki Kruskal-Wallis testi ile değerlendirildi. İstatistiksel değerlendirmede anlamlılık düzeyi $p<0.05$ olarak kabul edildi.

\section{BULGULAR}

Şubat ve Mart 2021 döneminde yatarak nörolojik rehabilitasyon uygulanan toplam 57 hastaya tilt table tedavisi uygulandı. Beş hasta çalışmaya

katılmayı reddetti, 3 hasta kontrolsüz hipertansiyon, 3 hasta kardiyovasküler hastalık, 2 hasta psikiyatrik hastalık tanısı (depresyon), 1 hasta iletişim bozukluğu (afazi) ve 4 hasta (anksiyete/depresyon ile ilgili) psikiyatrik ilaç kullanım öyküsü nedeniyle dışlandı.

Kesitsel dizayna sahip bu çalışmaya toplam 39 hasta (12 kadın, 27 erkek) dahil edildi. Hastaların yaş ortalaması $43 \pm 17,7$ yıl idi. Çalışmaya alınan 23 hasta spinal kord yaralanması, 12 hasta inme, 2 hasta travmatik beyin hasarı ve 2 hasta Parkinson hastalığı nedeniyle nörolojik rehabilitasyon görmekteydi. Hastaların demografik ve klinik özellikleri Tablo I'de verilmiştir.

Tablo I: Çalışma grubunun demografik ve klinik özellikleri $(\mathrm{n}=39)$.

\begin{tabular}{|c|c|}
\hline Yaş & $43 \pm 17,7$ \\
\hline \multicolumn{2}{|l|}{ Cinsiyet } \\
\hline Kadın / Erkek & $12(\% 30,8) / 27(\% 69,2)$ \\
\hline \multicolumn{2}{|l|}{ Tanı } \\
\hline Spinal kord yaralanması & $23(\% 59)$ \\
\hline Servikal & $15(\% 38,5)$ \\
\hline Torakal & $3(\% 7,7)$ \\
\hline Lumbosakral & $5(\% 12,8)$ \\
\hline İnme & $12(\% 30,8)$ \\
\hline Travmatik beyin hasarı & $2(\% 5,1)$ \\
\hline Parkinson Hastalığı & $2(\% 5,1)$ \\
\hline Hastalık süresi (ay) & $9(1-120)$ \\
\hline Fonksiyonel Bağımsızlık Ölçeği & $59,9 \pm 15,8$ \\
\hline Beck Anksiyete Ölçeği & $10(1-46)$ \\
\hline \multicolumn{2}{|l|}{ Ortostatik hipotansiyon gelişimi } \\
\hline Evet & $22(\% 56,4)$ \\
\hline $\begin{array}{ll}\text { Spinal } & \text { kord } \\
\text { yaralanması } & \end{array}$ & $16(\% 72,72)^{*}$ \\
\hline İnme & $4(\% 18,18)^{*}$ \\
\hline Travmatik beyin hasarı & $1(\% 4,54)^{*}$ \\
\hline Parkinson Hastalığı & $1(\% 4,54)^{*}$ \\
\hline Hayır & $17(\% 43,6)$ \\
\hline $\begin{array}{l}\text { Ortostatik hipotansiyon gelişim } \\
\text { süresi (dakika) }\end{array}$ & $8,5(4-20)$ \\
\hline
\end{tabular}


Tilt table tedavisi uygulanan hastalardan 22'sinde (8 kadın, 14 erkek) OH gelişirken, 17 hastada ( 4 kadın, 13 erkek) tedavi süresince $\mathrm{OH}$ gelişmedi (Tablo I ve II). Çalışma grubumuzdaki spinal kord yaralanmalı hastaların \%69,5'inde, inmeli hastaların ise \%33,3'ünde nörojenik $\mathrm{OH}$ gelişti.

Hastalar, nörojenik $\mathrm{OH}$ gelișen ve gelişmeyenler olarak iki gruba ayrıldığında her iki grubun yaş, cinsiyet, hastalık süresi ve FBÖ skorları benzerdi. İki grubun BAÖ skorları karşılaştırıldı ve anlamlı fark bulunamadı $(\mathrm{p}=0.580)$ (Tablo II).

Tablo II: Ortostatik hipotansiyon gelişen ve gelişmeyen gruplar arasında hasta özelliklerinin karşılaştırılması.

\begin{tabular}{|l|l|l|l|}
\hline & $\begin{array}{l}\text { OH gelişen } \\
(\mathrm{n}=22)\end{array}$ & $\begin{array}{l}\text { OH gelişmeyen } \\
(\mathrm{n}=17)\end{array}$ & $\mathrm{p}$ \\
\hline Yaş & $\begin{array}{l}41.18 \pm 18.2 \\
1\end{array}$ & $45.35 \pm 17.47$ & 0.475 \\
\hline $\begin{array}{l}\text { Cinsiyet } \\
\text { (Kadın/Erkek) }\end{array}$ & $8 / 14$ & $4 / 13$ & 0.307 \\
\hline Hastalık süresi (ay) & $7(1-66)$ & $10(1-120)$ & 0.416 \\
\hline $\begin{array}{l}\text { Fonksiyonel } \\
\text { Bağımsızlık Ölçeği }\end{array}$ & $\begin{array}{l}61.72 \pm 15.6 \\
\text { Anksiyete }\end{array}$ & $57.64 \pm 16.2$ & 0.432 \\
\hline $\begin{array}{l}\text { Beck } \\
\text { Ölçeği Ani }\end{array}$ & $7(1-32)$ & 0.580 \\
\hline
\end{tabular}

OH: Ortostatik hipotansiyon. Veriler ortalama \pm standart sapma ve median (minimum-maksimum) şeklinde verilmiştir. $p<0.05$ istatistiksel anlamlı düzey olarak kabul edilmiștir.
$\mathrm{OH}$ gelişen hastalarda hipotansiyon gelişme süresi ile yaş, hastalık süresi, FBÖ ve BAÖ arasındaki ilișki incelendi ve bu parametreler arasında anlamlı korelasyon gözlenmedi (Tablo III). $\mathrm{OH}$ gelişen hastalar BAÖ düzeylerine göre (0-7; minimal $(n=7), 8-15$; hafif $(n=9), 16-25$; orta $(n=3)$ ve 26-63; yüksek düzeyde anksiyete $(\mathrm{n}=3)$ şeklinde) gruplandırıldı. Bu gruplar arasında $\mathrm{OH}$ gelişim süresi açısından anlamlı bir fark yoktu $(\mathrm{p}=0.424)$.

Tablo III: Ortostatik hipotansiyon gelișen hastalarda ortostatik hipotansiyon gelişme süresi ile klinik ve anksiyete skorları arasındaki ilişki ( $\mathrm{n}=22)$.

\begin{tabular}{|c|l|l|l|l|}
\hline & Yaş & $\begin{array}{l}\text { Hastalık } \\
\text { süresi }\end{array}$ & FBÖ & $\begin{array}{l}\text { Beck } \\
\text { anksiyete } \\
\text { ölçeği }\end{array}$ \\
\hline OH gelişim süresi & -0.320 & -0.098 & 0.021 & -0.306 \\
$\mathrm{r}$ & 0.147 & 0.663 & 0.925 & 0.166 \\
\hline
\end{tabular}

Korelasyon 0.01 düzeyinde anlamlı.**, Korelasyon 0.05 düzeyinde anlamlı. $^{*}$ FBÖ: Fonksiyonel bağımsızlık ölçeği, OH: Ortostatik hipotansiyon.

$\mathrm{OH}$ gelişen hastalar arasında, kadınlarda anksiyete skoru erkeklere kıyasla daha yüksek bulundu ( $\mathrm{p}=0.048)$, OH gelişmeyen grupta ise cinsiyet açısından anksiyete skorları benzerdi $(p=0.111)$ (Şekil 1).
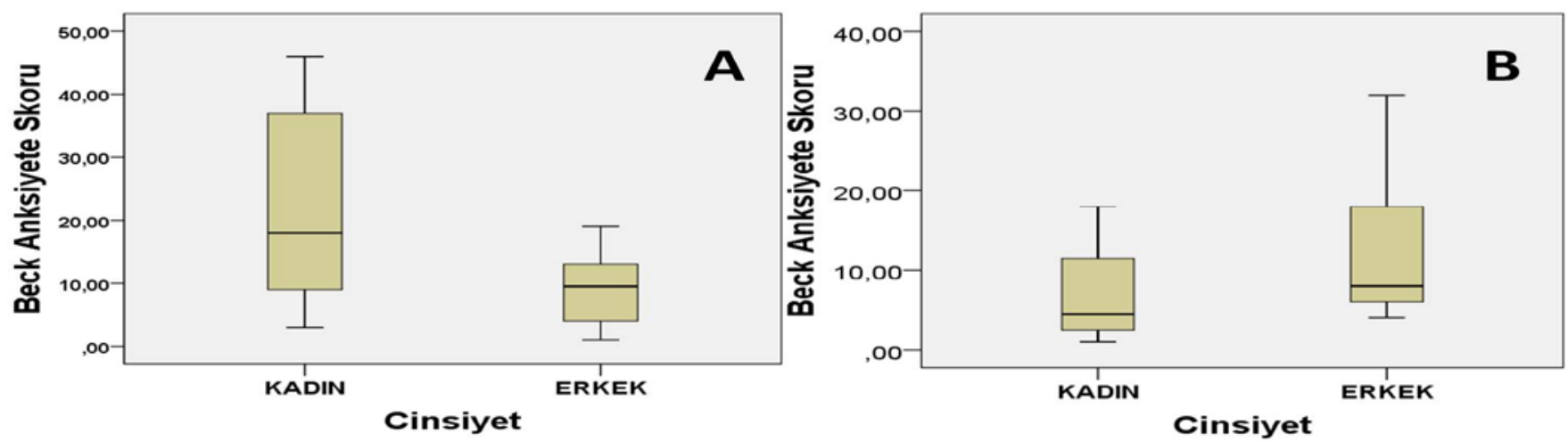

Şekil 1: Cinsiyet ve Beck anksiyete skorları arasındaki ilişki; A) Ortostatik hipotansiyon gelişen grupta kadınlarda anksiyete skoru erkeklere kiyasla daha yüksek ( $\mathrm{p}=0.048)$, B) Ortostatik hipotansiyon gelişmeyen grupta cinsiyet açısından anksiyete skorları benzer ( $\mathrm{p}=0.111)$. 
$\mathrm{OH}$ gelișen hastaların \%63,6'sı birden fazla semptomu aynı anda yaşadıklarını bildirirken (baș dönmesi, halsizlik, terleme) hastaların \%31,8'inde tek semptom olarak baş dönmesi ortaya çıktı.

\section{TARTIŞMA}

$\mathrm{Bu}$ çalışmanın sonuçlarına göre nörolojik rehabilitasyon gören hastalardan tilt table tedavisi uygulananlarda nörojenik $\mathrm{OH}$ gelişimi ile anksiyete arasında anlamlı bir ilişki gösterilemedi. Ayrıca, $\mathrm{OH}$ gelişen hastalar anksiyete düzeylerine göre gruplandırıldığında (minimal, hafif, orta, yüksek olarak), $\mathrm{OH}$ gelişim süresi açısından gruplar arasında anlamlı bir fark tespit edilmedi. $\mathrm{OH}$ gelişen hastalarda, hipotansiyon gelişme süresi ile anksiyete, yaş, hastalık süresi ve fonksiyonel bağımsızlık düzeyi arasında ilişki gözlenmedi. $\mathrm{OH}$ gelişen kadınlarda anksiyete skoru erkeklere kıyasla daha yüksekken, $\mathrm{OH}$ gelişmeyen grupta cinsiyetler arasında fark yoktu.

Nörojenik $\mathrm{OH}$, kardiyovasküler otonomik disfonksiyonun görüldüğü bazı hasta gruplarında sıklıkla görülmektedir. $\mathrm{Bu}$ hastalıklar arasında spinal kord yaralanması, inme, Parkinson hastalığı, multipl skleroz, pür otonom yetmezlik, multisistem atrofisi, otoimmun otonomik ganglionopati/nöropati, otozomal dominant lökodistrofi ve ailesel disotonomi bulunur ${ }^{5,23}$. $\mathrm{Bu}$ hastalıklardan rehabilitasyon kliniklerinde en sık spinal kord yaralanması görülür. Özellikle servikal bölgede ve 6. torakal omurga seviyesi üzerinde spinal kord yaralanması olan hastalar $\mathrm{OH}$ gelişimine daha yatkındır ${ }^{3,4}$. Bizim çalışma popülasyonumuz da en slk spinal kord yaralanmalı hastaları içermekteydi ve $\mathrm{OH}$ gelişen hastaların çoğu da bu gruptan idi.

Vazovagal senkop hastalarında anksiyete sıklığının \%45-80 gibi yüksek oranlarda olduğu ve bu hastalarda anksiyetenin tedavi edilmesi ile senkop ataklarının sıklığında azalma olduğu bildirilmiştir ${ }^{24}$. Ayrıca, kardiyak hastalarda yapılan bir çalışmada anksiyete düzeyi yüksek olan hastalarda tilt table testinin pozitiflik oranında artış olduğu bildirilmiş ve anksiyetenin katekolamin salınım dengesini bozarak vasküler ve kardiyak mekanoreseptörlerin uyarılmasında değişikliğe neden olduğu öne sürülmüştür ${ }^{12}$. Nörolojik rehabilitasyon uygulanan hastalarda anksiyete sıklığı belirgin bir şekilde artmıştır ${ }^{25}$. Ancak nörolojik rehabilitasyon hastalarında $\mathrm{OH}$ gelişiminde anksiyetenin etkisinin olup olmadığ 1 literatürde incelenmemiştir. $\mathrm{Bu}$ amaçla çalışmamızda hastaların anksiyete düzeyi değerlendirildi. Ancak $\mathrm{OH}$ gelişen ve gelişmeyen gruplar arasında anksiyete açısından belirgin fark görülmedi. Bu durum çalışmanın kesitsel dizaynı ve populasyonumuzdaki hastaların anksiyete skorlarının çok yüksek olmaması ile açıklanabilir.

$\mathrm{Bu}$ çalışmanın ikinci hipotezi nörojenik $\mathrm{OH}$ gelişen grupta yüksek anksiyete düzeylerinin nörojenik $\mathrm{OH}$ gelişim süresini kısaltabileceği idi. Yapılan çalışmalarda ek sistemik hastalığı olmayan vazovagal senkop hastalarının psikolojik profillerinde anksiyete, korku, depresyon ve panik bulgularının yaygın olarak görüldüğ̈̈11,12,26,27 ve uygulanan kognitif ve davranışsal tedavilerin senkop gelişimini azaltmada faydalı olabileceği bildirilmiștir ${ }^{21,27}$. Diğer yandan, pozisyonel $\mathrm{OH}$ hastalarında anksiyete ile semptom gelişimi arasında ilișki olmadığını bildiren çalışmalar da vardır ${ }^{28}$. Çalışmamızda nörojenik $\mathrm{OH}$ gelişen hastalar anksiyete düzeyleri minimal, hafif, orta ve yüksek olarak gruplandırıldığında $\mathrm{OH}$ gelişim süresinin gruplar arasında benzer olduğu görüldü. Yüksek anksiyete düzeyinin $\mathrm{OH}^{\prime} \mathrm{u}$ tetikleyici ve kötüleștirici etkisi gösterilemedi. Çalışma popülasyonunun heterojen olması nedeniyle hastaların nörojenik $\mathrm{OH}$ etyolojisinde birbirinden farklı, karmaşık ve multifaktöriyel mekanizmaların bulunması da bu sonuçta etkili olabilir. Diğer yandan, yukarıda bahsedilen 
çalışmalar, bizim çalışmamızdan farklı olarak sağlıklı bireyler üzerinde yapılmıştır.

Nörojenik $\mathrm{OH}$ gelișen hastalarda, $\mathrm{OH}$ gelișim süresiyle ilişkili faktörler literatürde çalışılmamıştır. Bununla birlikte hastalık süresi arttıkça kompanzatuar mekanizmaların devreye girmesi ile $\mathrm{OH}$ gelişme süresinin uzaması beklenir ${ }^{4}$. Hasta yaşı arttıkça otonomik regülasyonun bozulması ile ${ }^{29}$ yaşlı hastalarda daha kısa sürede $\mathrm{OH}$ gelişebilir. Ayrıca fonksiyonel durumu daha kötü olan hastalarda nörolojik hasarın şiddetine bağlı olarak daha ağır otonomik etkilenme oluşacağını ${ }^{3}$ ve böylece $\mathrm{OH}$ gelişim süresinin kısalabileceğini öngörmüştük. Ancak elde ettiğimiz sonuçlar bu hipotezi desteklemedi. Çalışmamızda anksiyetenin yanı sıra fonksiyonel durumun, hastalık süresinin ve yaşın da $\mathrm{OH}$ gelişim süresiyle belirgin bir ilişkisi ortaya konulamadı. Hasta sayısının kısıtlı olması bu sonuçlarda etkili olabilir.

Daha önceki çalışmalarda psikolojik faktörlerin vasovagal senkop üzerindeki etkisinin kadınlarda erkeklere oranla daha fazla olduğu bildirilmiştir ${ }^{4,12,21,27}$. Bizim çalışmamızda nörojenik $\mathrm{OH}$ gelişen grupta kadınlardaki anksiyetenin erkeklere göre yüksek olduğu görüldü, gelişmeyen grupta ise fark yoktu. Cohen ve ark. tilt table testi uygulanan nörokardiyojenik senkop hastalarında test pozitifliği ile anksiyete arasındaki ilişkinin kadınlarda daha belirgin olduğunu ve kadınlardaki yüksek anksiyete düzeylerinin senkop gelişimi için prediktif değer taşıdığını bildirmişlerdir ${ }^{12}$. Anksiyetenin, kadınlarda daha belirgin olmak üzere, $\mathrm{OH}^{\prime}$ un altında yatan otonomik yanıtlarda düzensizliğe neden olduğu öne sürülmüştür. Bizim de sonuçlarımızda gördüğümüz şekilde, nörojenik $\mathrm{OH}^{\prime} l u$ kadın hastalarda görülen yüksek anksiyete düzeyinin klinik öneminin ve hasta özelliklerine göre yaklaşım sonuçlarının belirlenmesi açısından daha kapsamlı çalışmalara ihtiyaç vardır.
$\mathrm{Bu}$ çalışmanın kısıtlılıkları; tek merkezde yapılmış kesitsel dizaynda bir çalıșma olması, hasta sayısının sınırlı olması, çalışma populasyonunun heterojenliği ve hastanın yatışı sırasında depresyon gibi diğer psikolojik faktörlerin değerlendirilmemesidir.

Sonuç olarak, bu çalışmada nörolojik rehabilitasyon gören hastalardan tilt table tedavisi uygulananlarda anksiyete ile nörojenik $\mathrm{OH}$ gelişimi arasındaki ilişki incelenmiş ancak anlamlı bir ilişki tespit edilmemiştir. Nörojenik OH'lu kadın hastalarda daha yüksek anksiyete olmasının klinik öneminin ve hasta özelliklerine göre yaklaşım sonuçlarının belirlenmesi açısından daha kapsamlı çalışmalara ihtiyaç vardir.

DİPNOT: Bu çalışma, 8-11 Nisan 2021 tarihleri arasında yapılan 28. Uluslararası Katılımlı Ulusal Fiziksel Tip ve Rehabilitasyon Kongresinde sözlü bildiri olarak sunulmak üzere kabul edilmiştir.

Etik Kurul Kararı: Afyonkarahisar Sağlık Bilimleri Üniversitesi Klinik Araştırmalar Etik Kurulu'ndan 05.02.2021 tarihinde 2021/111 numara ile etik kurul onayı alınmıştır.

Çıkar Çatışması Beyanı: Çıkar çatışması bulunmamaktadır.

Finansal Destek: Bu çalışma her hangi bir fon tarafından desteklenmemiştir.

Declaration of Conflicting Interests: The author declare that she has no conflict of interest.

Financial Disclosure: No financial support was received.

\section{KAYNAKLAR}

1. Cutsforth-Gregory JK, Low PA. Neurogenic Orthostatic Hypotension in Parkinson Disease: A Primer. Neurol Ther 2019; 8: 307-24.

2. Illman A, Stiller K, Williams M. The prevalence of orthostatic hypotension during physiotherapy 
treatment in patients with an acute spinal cord injury. Spinal Cord 2000; 38: 741-7.

3. Dernek B, Oral A, Aydın R, Çapan N, Esmaeilzadeh S. Cervical spinal cord injury presenting with refractory orthostatic hypotension: a case report. Turk J Phys Med Rehab 2016; 62: 162-6.

4. Wecht JM, Bauman WA. Implication of altered autonomic control for orthostatic tolerance in SCI. Auton Neurosci 2018; 209: 51-8.

5. Eschlbock S, Wenning G, Fanciulli A. Evidencebased treatment of neurogenic orthostatic hypotension and related symptoms. J Neural Transm (Vienna) 2017; 124: 1567-605.

6. Yoshida T, Masani K, Sayenko DG, et al. Cardiovascular response of individuals with spinal cord injury to dynamic functional electrical stimulation under orthostatic stress. IEEE Trans Neural Syst Rehabil Eng 2013; 21: 37-46.

7. Gibbons CH, Schmidt P, Biaggioni I, et al. The recommendations of a consensus panel for the screening, diagnosis, and treatment of neurogenic orthostatic hypotension and associated supine hypertension. J Neurol 2017; 264: 1567-82.

8. Çırak M, Irmak HS. Analysis of Fall Risk Factors in Elderly with Neurological Disease. Turkiye Klinikleri J Med Sci 2020; 40: 297-305.

9. Perlmuter LC, Sarda G, Casavant V, Mosnaim AD. A review of the etiology, associated comorbidities, and treatment of orthostatic hypotension. Am J Ther 2013; 20: 279-91.

10. Chelvarajah R, Knight SL, Craggs MD, Middleton FR. Orthostatic hypotension following spinal cord injury: impact on the use of standing apparatus. NeuroRehabilitation 2009; 24: 237-42.

11. Giada F, Silvestri I, Rossillo A, et al. Psychiatric profile, quality of life and risk of syncopal recurrence in patients with tilt-induced vasovagal syncope. Europace 2005; 7: 465-71.

12. Cohen TJ, Thayapran N, Ibrahim B, et al. An association between anxiety and neurocardiogenic syncope during head-up tilt table testing. Pacing Clin Electrophysiol 2000; 23: 837-41.

13. Widerstrom-Noga E, Cruz-Almeida Y, Krassioukov A. Is there a relationship between chronic pain and autonomic dysreflexia in persons with cervical spinal cord injury? J Neurotrauma 2004; 21: 195-204.

14. Hall KM, Cohen ME, Wright J, Call M, Werner P. Characteristics of the Functional Independence Measure in traumatic spinal cord injury. Arch Phys Med Rehabil 1999; 80: 1471-6.

15. Kidd D, Stewart G, Baldry J, et al. The Functional Independence Measure: a comparative validity and reliability study. Disabil Rehabil 1995; 17: 10-4.

16. Muslimovic D, Post B, Speelman JD, et al. Determinants of disability and quality of life in mild to moderate Parkinson disease. Neurology 2008; 70: 2241-7.

17. Corrigan JD, Smith-Knapp K, Granger CV. Validity of the functional independence measure for persons with traumatic brain injury. Arch Phys Med Rehabil 1997; 78: 828-34.

18. Kucukdeveci AA, Yavuzer G, Elhan AH, Sonel B, Tennant A. Adaptation of the Functional Independence Measure for use in Turkey. Clin Rehabil 2001; 15: 311-9.

19. Ulusoy M, Sahin NH, Erkmen H. Turkish Version of the Beck Anxiety Inventory: Psychometric Properties. J Cogn Psychother 1998; 12: 163-72.

20. Çelik RGG, Nalbantoglu M, Köseoğlu M, et al. The Frequency of Non-Epileptic Seizures in Epileptic Patients, the Relationship with Anxiety and Depression. Dicle Med J 2020; 47: 260-7.

21. Lee SH, Park SJ, Byeon K, et al. Prevalence and clinical factors of anxiety and depression in neurally mediated and unexplained syncope. Yonsei Med J 2013; 54: 583-9.

22. Baltz MJ, Lietz HL, Sausser IT, Kalpakjian C, Brown D. Tolerance of a standing tilt table protocol by patients an inpatient stroke unit setting: a pilot study. J Neurol Phys Ther 2013; 37: 9-13.

23. Aygun D, Akpinar C, Yon S, Onar M. Effect of clinical autonomic dysfunction on cognitive functions in Parkinson's disease. Dicle Med J 2017; 44: 225-31.

24. Atici A, Asoglu R, Demirkiran A, et al. The relationship between clinical characteristics and psychological status and quality of life in patients 
with vasovagal syncope. North Clin Istanb 2020; 7 : 237-45.

25. Hampson N, King L, Eriksson LM, Smee H. The effects of relaxation training on depression and anxiety in people living with long-term neurological conditions. Disabil Rehabil 2020; 42: 2100-5.

26. Gracie J, Newton JL, Norton M, Baker C, Freeston M. The role of psychological factors in response to treatment in neurocardiogenic (vasovagal) syncope. Europace 2006; 8: 636-43.
27. Brisinda D, Brocca L, Sorbo AR, et al. Psychophysiological evaluation of patients with transient consciousness loss of uncertain origin. Kardiol Pol 2018; 76: 566-73.

28. Wagner $\mathrm{C}$, Isenmann $\mathrm{S}$, Ringendahl $\mathrm{H}$, Haensch CA. [Anxiety in patients with postural tachycardia syndrome (POTS)]. Fortschr Neurol Psychiatr 2012; 80: 458-62.

29. Salcı Y, Balkan AF, Ceren AN, et al. Investigation of Professional Opinions About Early Mobilization After Stroke. Dicle Med J 2019; 46: 261-8. 